\title{
塩化鉄 $(\mathrm{III})-\mathrm{LiAlH}_{4}$ 系触媒の水素添加活性に及ぼす溶媒（添加物）の影響*1
}

\author{
(昭和 41 年 2 月 7 日受理)
}

武上善信・上野徹・藤井隆雄 ${ }^{* 2}$

\begin{abstract}
塩化鉄 (III) - $\mathrm{LiAlH}_{4}$ 系オレフィン水素添加触媒はエーテル系溶媒中で良好な活性を示し, その活性は $\mathrm{LiAlH}_{4} / \mathrm{FeCl}_{3} モ ル 1$ 此に依 存している(モル比 1.0 1.2 が最適）。エーテル系溶媒中の触媒の活性をスチレン水素添加について比較すると，ジーnーブチルェ

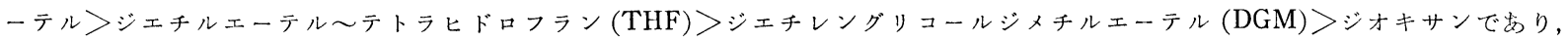
また一定触媒量で水素添加できるスチレンの量を比較すると, DGM >ジーnーブチルエーテル>THF>ジェチルエーテル>ジオキサ ンである。

本触媒系の溶媒としてトルェンのよ5な炭化水素溶媒を用いた場合は活性な触媒は生成しないが，これに少量の THF を添加す ると活性な触媒が生成した。したがって本触媒系にはエーテル系配位子が必要であると考光られる。しかしピリシン，トリフェニ ルホスファイトなど壏基性の強い配位子を添加すると活性が低下した。
\end{abstract}

\section{1 緒言}

著者らは，前報1,2!に招いて，テトラヒドロフラン (THF) を溶 媒として無水重金属壏と $\mathrm{LiAlH}_{4}$ を反岕させたとき生成する黑色 物質が高いオレフィン水素添加触媒活性を有していること扣よび その触媒活性が $\mathrm{LiAlH}_{4}$ 対重金属塩モル比（以下これを単にモル 比と呼ぶ）に依存していることなどを報告し，主として塩化鉄 (III) $-\mathrm{LiAlH}_{4}$ 系触媒についての梌捨から, この鉄触媒の触媒活性 の主体をなしているものは鉄水素化物であると結論した。

これまで本触媒系の溶媒として THF 以外には十分な検討を行 なったことがなかったので, 本報では, ジェチルェーテル, ジオ キサン, ジブチルェーテル, ジェチレングリコールジメチルエー テル (DGM) 执よびトルェンを溶媒とした場合の塩化鉄(III)-Li・ $\mathrm{AlH}_{4}$ 系触媒の 水素添加活性を検討し, あわせて, 活性の高い THF 溶媒の触媒にピリジンなどの二, 三の塩基性物質を添加した ときの触媒活性の低下について検邻した。

\section{2 実験}

$2 \cdot 1$ 試 料 $\mathrm{LiAlH}_{4}$ は Metal Hydride 社製のものを使用し た。各溶媒は金属ナトリウムで, ピリジンは水素化カルシウムで 脱水し，それぞれ使用直前に精留した。その他の試薬は市販品を そのまま用いた。

\section{$2 \cdot 2$ 装 置 前報 ${ }^{1 \sim 3)}$ と同じ装置を用いた。}

$2 \cdot 3$ 操 作 ジェチルェーテル, ジーn-ブチルェーテル. THF および DGM 溶媒の場合には, $\mathrm{LiAlH}_{4}$ を溶液 $(0.20 \sim 0.25 \mathrm{~mol} / l)$ として用い, 前報1,2) と同様にして触媒を合成した。ジオキサン およびトルェン溶媒の場合には, $\mathrm{LiAlH}_{4}$ の固体に溶媒を滴下し た。スチレンの水素添加は前報1,2) の方法によって, ジオキサン 溶媒の場合には $35^{\circ} \mathrm{C}$ で, その他の溶媒の場合には $0^{\circ} \mathrm{C} て ゙$ でなっ た。触媒の塩酸分解, スチレン処理なども前報 ${ }^{2)}$ と同様に行なっ た。

*1 本報を「重金属水素化物の合成およびその触媒作用（第 10 報)」と与る。前報：武上, 上: 野, 坂田, 工化, 68, 2373 (1965).

*2 Yoshinobu Takegami, Toru Ueno, Takao FujII 京 都大学:工学部然料化学教室: 京都市左京区吉田.

1) 武上, 上野, 工化, 67, 246 (1964).

2) 武上, 上野, 藤井, 工化, 67, 1009 (1964).

3) 武上, 上野, 河尻, 触媒, 4, 13 (1962).

\section{3 結果および考察}

\section{$3 \cdot 1$ ジエチルエーテル溶媒}

$\mathrm{LiAlH}_{4}$ と塩化鉄 (III) をモル比 0.3 付近で反応させると反応 液はこげ茶色に着色し, モル比の增加とともに黒色が強くなり, モル比 0.8 以上では黒色となる。この反応混合物を一晚放置する と無色透明の上澄液と黒色沈殿に分離する。この反応混合物は塩 酸で速やかに分解する。分解液は無色透明であるが空気に触れる と淡黄色に着色する。触媒の合成時扣よび塩酸分解時の水素発生 量と触媒のモル比との関係を図1に示した。な打比較のために, 前報2)の THF 溶媒の場合の結果も図1亿示した。

図 $2 \mathrm{~A}$ に，モル比の異なる数種の触媒を用いてスチレンの水 素添加を行なった場合の水素吸収曲線を示した。最大の活性はモ ル比 1.2 で現われ, この最適モル比の值は THF 溶媒の場合の 1.0 よりるやや大きい。

窒素雾团気下でこの触媒をスチレンと反応 $\left(0^{\circ} \mathrm{C}, 2\right.$ 時間) させ た*3ときのエチルベンゼン生成量 $\left(\mathrm{mol} / \mathrm{mol}-\mathrm{FeCl}_{3}\right.$ で表示) と触 媒のモル比との関倸を図 3 に示した。比較のため, THF 溶媒の

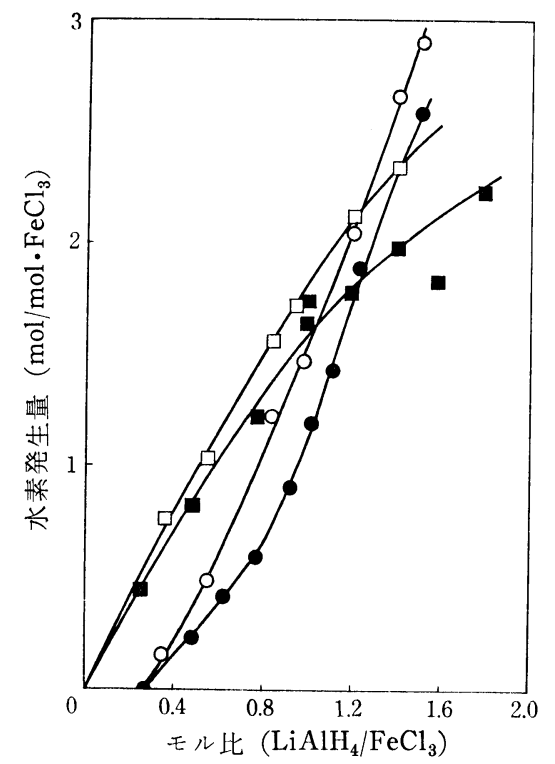

四 1 触媒合成時ならびに塩酸分解時の水素発生量

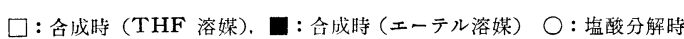
(THF 溶媒), ・ : 塩酸分解時 (エーテル溶媒) 


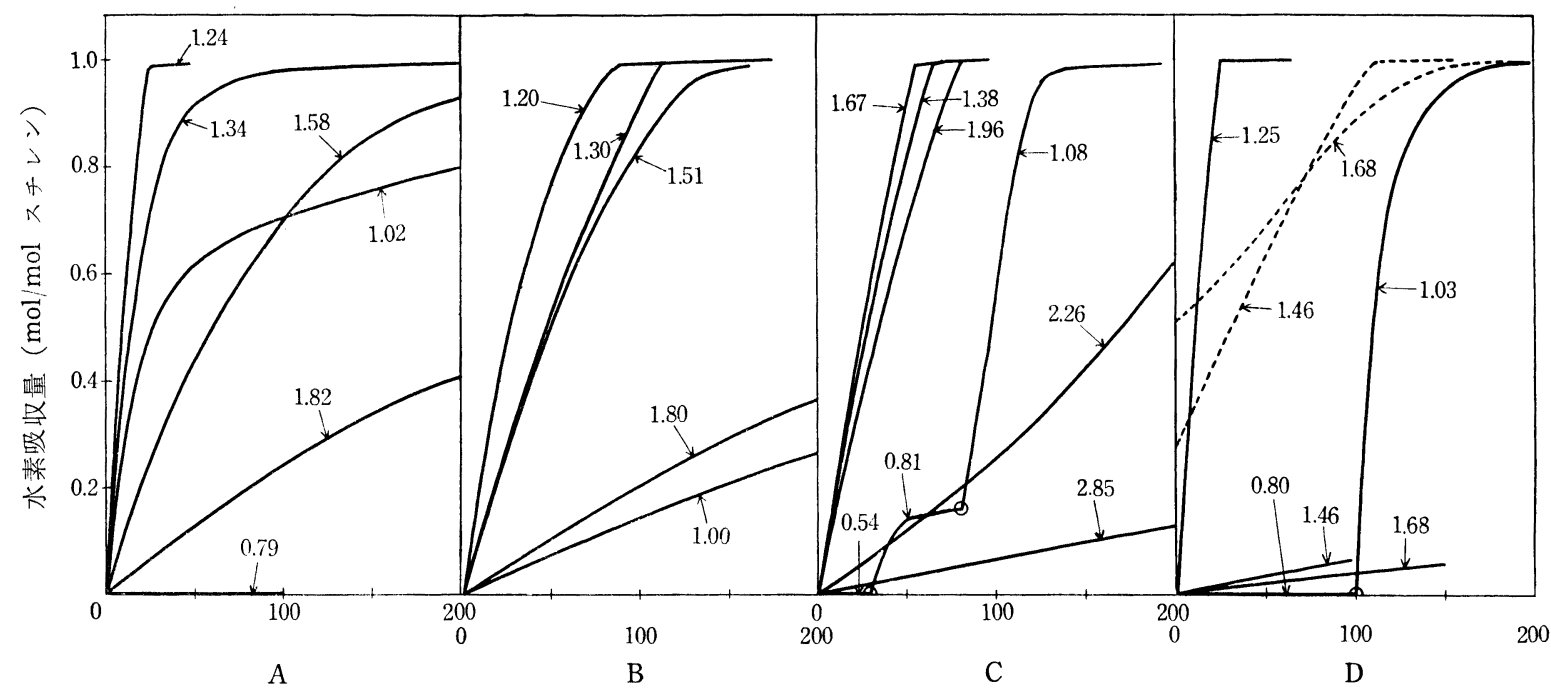

反 応時間 $(\min )$

図2 ス 2 ン の水素添加反応

图中の数字は $\mathrm{LiAlH}_{4} / \mathrm{FeCl}_{3}$ モル比を示す

$\mathrm{A}$ ：ジェチルェーテル浴媒， B ：ジオキサン溶媒， C：DGM 溶媒，D：ジーnーブチルエーテル溶媒 （な怙図Dの点線は一脕放㯰後の水素吸收を示す）

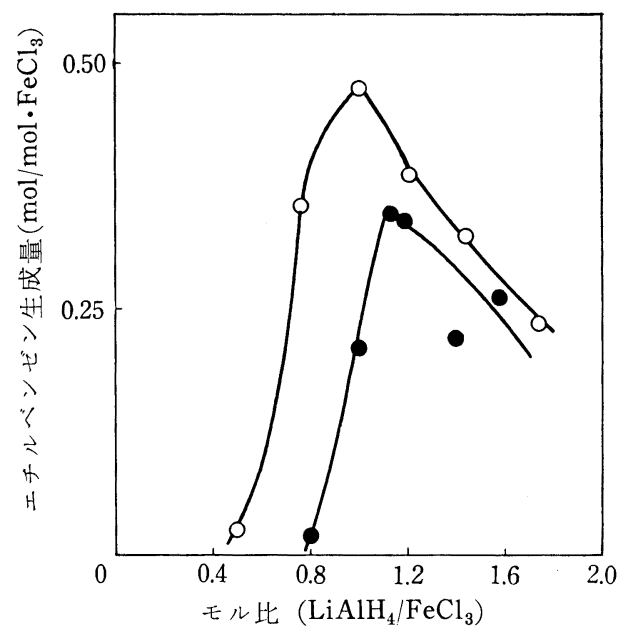

図 3 触媒のスチレン処理

$\mathrm{O}: \mathrm{THF}$ 溶媒, @ : ジェチルェーテル溶媒

触媒の場合の結果 ${ }^{2}$ も示した。このエチルベンゼンの生成は前 報2)で論じたように触媒からスチレンへの水素移動によるものと 考光らるものであり, 図 3 より明らかなように, エチルベンゼ ン生成量は触媒のモル比に依存して打り，エチルベンゼン生成量 が最大になるモル比は触媒活性が最大になるモル比に一致してい る。しかしその移動水素量は全般にエーテル溶媒の場合の方が THF 溶媒の場合よりも小さい。また図1から明らかなように触 媒の塩酸分解特の水素発生量も, 同じモル比の触媒についてはェ 一テル溶媒の場合の方が THF 溶媒の場合に比べて小さくなって 扣り，これらのことからエーテル溶媒中で合成した触媒の方が保 有水素量が少ないるのと考光られる。

Schaeffer ら) はジェチルェーテル溶媒中での $\mathrm{LiAlH}_{4}$ と塩化 鉄(III)の反応について研究して拈り，モル比 1.0 以下では $\mathrm{AlH}_{3}$ が生成し，モル比が 1.0 より大きくなる $\mathrm{Fe}\left(\mathrm{AlH}_{4}\right)_{2}$ が生成す

*3 以後この操作をスチレン処理と呼ぶ。
るが，これは徐々に分解して水素を失い最終的には金属になると 報告している*。 しかし，著者らのジェチルェーテル溶媒の場合 の触媒合成時および塩酸分解時の水素発生量(図 1 ) は Schaeffer らの機構から考号れるそれと一致しない。

さらに, ジェチルェーテル溶媒中で合成したモル比 1.0 の触媒 はスチレン処理によって $0.21 \mathrm{~mol} / \mathrm{mol}-\mathrm{FeCl}_{3}$ のエチルベンゼン を生成する（図 3 ）が, Schaeffer らの機構に従えば，この大部 分は $\mathrm{AlH}_{3}$ によって生成するものとしか考兄られない。しかるに $\mathrm{LiAlH}_{4}$ と $\mathrm{AlCl}_{3}$ との反応混合物 $\left(\mathrm{LiAlH}_{4}: \mathrm{AlCl}_{3}=3: 1\right.$, 溶媒 : THF) のスチレン処理によってはエチルベンゼンは生成しない ので，モル比 1.0 の触媒によるエチルベンゼンの生成は $\mathrm{AlH}_{3}$ によるものではないといえる。このことから，スチレンへの水素 移動ならびに水素添加活性を示す触媒の本質は Al-H 結合にある のではなく, $\mathrm{Fe}-\mathrm{H}$ 結合にあるものと考えられる。

\section{$3 \cdot 2$ ジオキサン溶媒}

THF 扣よびジェチルェーテル溶媒の場合には 10２0 分間で 水素の発生が注浣了するのに対して, ジオキサン溶媒の場合に は $0.3 \sim 0.5 \mathrm{~mol} / \mathrm{mol}-\mathrm{FeCl}_{3}$ の水素を発生した後, 約 3 時間の誘 導期がみられ，この誘導期の終りに反応液は黒色に着色した。

図 2 B にスチレン水素添加反応の結果を示した。最適モル比は 1.2 付近であり, これはェーテル溶媒の場合とほぼ同じで女る。

\section{$3 \cdot 3$ ジエチレングリコールジメチルエーテル溶媒}

DGM 溶媒中で $\mathrm{LiAlH}_{4}$ と塩化鉄( III)の反応を行なった場合, モル比 0.5 付近で黒色物質が得られた。図 $2 \mathrm{C}$ にスチレン水素 添加反応の結果を示した。最大の活性を示すモル比は $1 \sim 2$ であ り, 他の溶媒のときに比べて活性な触媒を与えるモル比の幅が極

4) G. W. Schaeffer, J. S. Roscoe, A.C. Stewart, J. Am. Chem. Soc., 78, 729 (1956).

*4 $\mathrm{FeCl}_{3}+\mathrm{LiAlH}_{4} \longrightarrow \mathrm{FeCl}_{2}+\mathrm{AlH}_{3}+\mathrm{LiCl}+1 / 2 \mathrm{H}_{2}$ $\mathrm{FeCl}_{2}+2 \mathrm{LiAlH}_{4} \longrightarrow \mathrm{Fe}\left(\mathrm{AlH}_{4}\right)_{2}+2 \mathrm{LiCl}$ $\mathrm{Fe}\left(\mathrm{AlH}_{4}\right)_{2} \stackrel{-\mathrm{H}_{2}}{\longrightarrow} \mathrm{FeAl}_{2} \mathrm{H}_{6} \stackrel{-3 \mathrm{H}_{2}}{\longrightarrow} \mathrm{Fe} \cdot 2 \mathrm{Al}$ $\mathrm{AlH}_{3} \longrightarrow \mathrm{Al}+3 / 2 \mathrm{H}_{2}$ 
めて広い。モル比が 2.85 に達しても, 尚, 多少の活性を示した。

\section{$3 \cdot 4$ ジーnーブチルエーテル溶媒}

ジーn-ブチルェーテル溶媒を用いた場合には，触媒合成時の水 素発生量が異常に大きく*5, 水素発生が完了するのに長時間 ( 3 時間〜 6 時間）を要した。スチレンの水素添加反応を行なった場 合の触媒の最適モル比は 1.2 付近にある（図 $2 \mathrm{D}$ )。モル比が大 き過ぎて活性が小さい場合には一晚放置する事によってかなり大 きい活性を示した（図 $2 \mathrm{D}$ の点線部）。ジーnーブチルェーテル溶 媒つ場合だけ触媒合成時の水素発生量が異常に大きく, かつ, 最 大活性を示すモル比は他の溶媒を用いた場合と大差がないのは興 味罙い事実でありこの点に関しては今後更に検討の予定である。

以上のように, 本触媒はエーテル系溶媒中で良好な水素添加活 性を示すが, エーテル系溶媒中に批ける触媒活性を比較すると次 のような順序になる：ジーnーブチルェーテル>ジェチルェーテル 〜 THE $>\mathrm{DGM}>$ ジオキサン. またジーn-ブチルエーテル溶媒中 のモル比 1.2 の触媒を用いてスチレンの水素添加を繰返し行な った場合（1回の水素添加に用いたスチレン: $26 \mathrm{~m} \mathrm{~mol}$ ) 7 回ま では触媒活性が落さることなく速やかに水素添加が完了した。こ のよ5な触媒の耐久性を各種溶媒中の最適モル比の触媒について 比較してみると次のよ5になる：DGM>ジ-n-ブチルェーテル $\langle\mathrm{THF}\rangle$ ジェチルェーテル>ジオキサン.

\section{$3 \cdot 5$ トルエン溶媒}

$\mathrm{LiAlH}_{4}$ と塩化鉄（III）（モル比 1.0）の反応をトルエン溶媒中 $0^{\circ} \mathrm{C}$ で行なった場合, 水素発生はみられず, 反応混合物はこげ茶 色となったのみで，この反応混合物はスチレン水素添加活性を示 さなかった。

反応温度 $60^{\circ} \mathrm{C}$ の場合には $1.1 \mathrm{~mol} / \mathrm{mol}-\mathrm{FeCl}_{3}$ の水素を発生し て黒色物質が生成し，このものはスチレン水素添加活性を示した が，その活性は極めて小さく，水素添加率は 200 分間で約 $1 \%$ であった。反応温度 $110^{\circ} \mathrm{C}$ の場合には $1.4 \mathrm{~mol} / \mathrm{mol} \cdot \mathrm{FeCl}_{3}$ の水 素を発生したが反応混合物はこげ茶色であり活性はなかった。

このよ5に反応温度を高くするとトルェン溶媒中でも塩化鉄 (III) と $\mathrm{LiAlH}_{4}$ の反応は進行する。THF 溶媒中で合成した触媒 は $65^{\circ} \mathrm{C}$ で数時間加熱しても活性を失わない1)ので, トルェン溶 媒中で合成した触媒の活性が極めて小さいのは, 生成した触媒の 安定度が小さいためであると思われる。 $0^{\circ} \mathrm{C}$ または $110^{\circ} \mathrm{C} て ゙$ 合成 した反応混合物にそれぞれ少量の THF を添加したところ，とも に黒色物質が生成した。これら両者ともスチレン水素添加活性觉 示したが, 後者の活性は極めて小さいものであった。

\section{$3 \cdot 6$ ピリジン,トリフェニルホスフィンおよびトリフェニルホ}

\section{スファイトの添加}

前項で述べたように, トルェン溶媒中の塩化鉄 (III) $-\mathrm{LiAlH}_{4}$ 混 合物に少量の THF を加えると触媒の生成が円滑に進行するので あるが，この事実は触媒が生成するためにはエーテル系配位子の 存在が必要であることを示唆しているすのと考えられる。そこで, 他の配位子の効果について若干の検討を試みた。配位子としては 一般によく用いられているピリジン, トリフェニルホスフィン, トリフェニルホスファイトを使用した。 $\mathrm{LiAlH}_{4}$ とピリジンは安 定な錯合化物を形成することが知られて㧊り ${ }^{5)}$, この錯化合物と

*5 たとえばモル比 1.23 のときの水素発生量は $3.86 \mathrm{~mol} / \mathrm{mol}$ $\mathrm{FeCl}_{3}$ であり,これは THF 溶媒の場合の約 1.8 倍にあ たる。
塩化鉄（III）を反応させても水素の発生はみられず，黑色物質も 生成しなかった。この反応混合物は全くスチレン水素添加活性を 示さなかった。したがって, ピリジンを本触媒系の溶媒として使 用することはできない。THF 溶媒中モル比1.0で合成された触 媒を用いた速やかなスチレン水素添加反応の途中でピリジンを添 加すると活性が低下し(図 4 ), その低下の程度はピリジン添加量 の増加とともに大きくなった。ピペリジンを用いて同様な実験を 行なったところ, 活性の低下はピリジンの場合より小さかった。 ピリジンをたはピペリジンを添加した反応混合物を塩酸分解する と $1.1 \sim 1.3 \mathrm{~mol} / \mathrm{mol}-\mathrm{FeCl}_{3}$ の水素を発生し, 無色透明となった。 また, 触媒とピリジンを $50^{\circ} \mathrm{C}$, 水素雾团気下で反応させると, 緩慢な水素吸収が起こり, 少量のピペリジンが生成した。

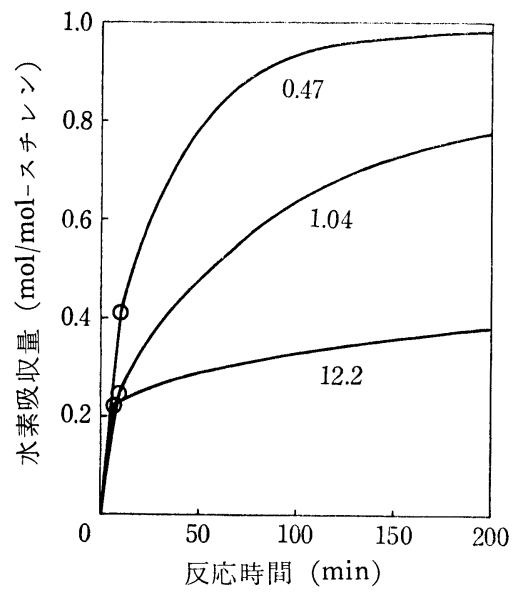

图 4 ピリジンの添加効果 図中の数字は $\mathrm{C}_{5} \mathrm{H}_{5} \mathrm{~N} / \mathrm{FeCl}_{3}$ モル比 ○印はピリジンを添加した点を示す

トリフェニルホスフィンを添加した場合には, 活性低下の程度 はピリジンの場合よりも小さく, トリフェニルホスフィンを触媒 の 2.3 倍モルまで加えてもスチレン水素添加速度は全く低下しな かった。スチレン水素添加の前に, 触媒を $0^{\circ} \mathrm{C} て ゙ 5 \sim 8$ 時間トリ フェニルホスフィン（2.3 倍モル）と反応させても活性に変化は みられないが， $50^{\circ} \mathrm{C}$ で 2 時間反応させると活性は著しく低下し た。この反応混合物を塩酸で分解したときの水素発生量は 0.60 $\mathrm{mol} / \mathrm{mol}-\mathrm{FeCl}_{3}$ と小さいものであり, 水素発生が完了しても黒色 のままであった。この分解液からベンゼンが確認された。

トリフェニルホスファイトを用いてピリジンの場合と同様な実 験を行なったところ著しい活性の低下がみられ，1 mol の添加に よってスチレン水素添加反応はほぼ停止した。塩酸分解後も黑色 のままであり, 水素発生量は $0.7 \mathrm{~mol} / \mathrm{mol}-\mathrm{FeCl}_{3}$ 程度であった。 この分解液からフェノールが検出された。

以上の結果より，これらの配位子の配位によって触媒活性が低 下すること，拉よび配位子が触媒と反応してその還元生成物を与 えることが明らかである。トリフェニルホスファイトを添加した 場合扣よびトリフェニルホスフィンと加熱した場合の著しい活性 低下の一因は, 添加物質と触媒との反応による触媒の形態変化で あると考觉れる。

(昭和 40 年 4 月, 日本化学会第 18 年会講演)

5) P. Lansbury, J. Peterson, J. Am. Chem. Soc., 83, 3537 (1961). 